\title{
Development of MSMEs (Micro, Small and Medium Enterprises) by Baitul Maal Wat Tamwil (BMT) as an Instrument for Poverty Reduction
}

\author{
Gina Noviana Yuniar
}

STIE EKUITAS, Bandung, Indonesia

Copyright (C) 2015 Horizon Research Publishing All rights reserved.

\begin{abstract}
MSME is a sector that plays an important role in economic development in Indonesia, seen from the significant contribution in employment. Accounted GDP, foreign exchange and giving donations. In carrying out its role, the MSMEs sector did not grow and develop without having a problem despite the development contribution is quite large. The problem that often occurs in the MSMEs sector are relatively complex, ranging from human resources issues, access to capital, business culture and management capability as well as fund management business that is mixed with household finances. This is what needs to be addressed by the related parties on an ongoing basis. It needs a real movement and implementable, one strategic effort to do is through the optimization of the role of Islamic Microfinance Institutions (LKMS) is Baitul Maal wat Tamwil (BMT). Given the banking institutions have not been able to touch the bottom of society (poor, poor and other dhu'afa). Their access to banking is very small, almost nothing at all. They also do not have collateral and are not good at making proposals. But with the BMT, they tried to improve the well-being of its clients with financing and assistance to customers.
\end{abstract}

Keywords MSMEs (Micro Small and Medium Enterprises), BMT (Baitul Maal wat Tamwil), LKMS (Islamic Microfinance Institutions), financing, MSMEs assistance

\section{Introduction}

MSME (Micro, Small and Medium Enterprises) is one part of the world economy which attracted much attention of researchers, academics, practitioners and policy makers because of its development. The increasing growth of MSMEs in Indonesia, especially the local scale is also influenced by a variety of actions taken by people who demanded they be better prepared to face the free market economy, that's the impact on the community for over switch professions as entrepreneurs or at least have a profession as MSMEs. MSMEs in recent decades increasingly prove tremendous role in helping solve the economic problems and create economic change in society by providing a lot of business innovation and business field. So now MSMEs become a major proponent of national economic growth, becomes a container for most of the labor force and even as a contributor to the GDP (Gross Domestic Product), the largest in our country. Contribution of MSMEs has been increasingly recognized by researchers and practitioners have attracted interest in the phenomenon of empowerment of MSMEs.

Poverty is a major issue in the national development agenda. The poverty rate in Indonesia is still very high, reaching $11: 47 \%$ or 28.07 million people (according to data from BPS 2013), has become a chronic problem that is causing the gap and unemployment. In this case the government has a central role should be extra to think fast and responsive action to address this issue. On the other hand, there is one Islamic microfinance institutions (LKMS) present the most strategic and functional in order to alleviate poverty is BMT (Baitul Maal wat Tamwil). BMT developments that are currently growing rapidly is a great potential in the microfinance sector. This potential can fill the role of banks in financing MSMEs and a force to be more optimal in poverty alleviation movement if she continued to be optimized.

The Chairman of the Association of BMT across Indonesia (Absindo), Aries Muftie, said the current number of BMT is more than 5,500. In accumulation, asset BMT is estimated to have reached around Rp 3 trillion dollars. Until today there has been approximately 3 million customers that utilize micro-finance services through BMT model of financial institutions in Indonesia. In terms of development financing provided, financing to deposit ratio (FDR), generally close to $100 \%$ and some even exceeded. This condition indicates that the funds raised from members and customers can be fully distributed. BMT good performance 
and beroprasi are effectively able to play a role in improving and encouraging people's economy in Indonesia. Aries Muftie was confident that the alleviation of poverty through the empowerment of SMEs can be realized by strengthening the effectiveness of BMT in Indonesia.

The emergence LKMS customers business sector plays an important role in poverty reduction. This opportunity is a challenge for the sector to be able to realize LKMS great job of this in order to create a productive economy by way of eradicating poverty, improving the quality of working capital and provide coaching and mentoring efforts to create empowering SME customers. Therefore, this paper is focused on optimizing the function and role of LKMS or BMT (Baitul Maal wat Tamwil) in an effort to the development of MSMEs (business customers) as an instrument to alleviate poverty by using the instruments working capital financing and business assistance. Potential provision of working capital financing and business assistance can be optimized by creating productive financing system, such as mudaraba and Musharaka financing with revenue sharing contract and business assistance periodically conducted by members of the BMT is an account office . This condition can create a business climate models or Islamic Shari'a compliant.

\section{Literature Review}

\subsection{Islamic Microfinance Institutions}

The success of Islamic banking in the homeland can not be separated from the role of Islamic Microfinance Institutions (LKMS). LKMS notch which, among others, presented by the SRB, BMT and the Cooperative Pesantren (Kopontren) and reaching vital Islamic transactions in areas that can not be served by commercial banks and the banks are opening Islamic business units. If you look at the economic empowerment of the people in the true sense, it can be seen from BMT gait. BMT is an institution that seeks to develop the people's economy productive ventures and investments with revenue sharing system to improve the quality of economic entrepreneurs or SMEs in order to alleviate poverty.

\subsection{MSME (Micro, Small and Medium Enterprises)}

MSME ( Micro, Small and Medium Enterprises ) is one sector that has great potential to improve the strategic and national economic activity. Law No. 20 of 2008 states that :

"Micro is a productive enterprise owned by individuals and or entities individuals who meet the criteria as set forth in Micro this Act"

"Small businesses are productive economic activities that stand alone, which is conducted by an individual or business entity that is not a subsidiary or branch company is not owned, controlled, or be a part either directly or indirectly from a medium or large businesses that meet the criteria Small Business as defined in this Act"

"Medium is productive economic activities that stand alone, which is done by the individual or business entity that is not a subsidiary or branch company owned, controlled, or be a part either directly or indirectly with Small or large businesses with total net assets annual sales or proceeds as provided in this Act"

MSME criteria according to Law No. 20 of 2008 Section 6, the following criteria :

\begin{tabular}{|c|c|c|c|}
\hline \multirow{2}{*}{ No. } & \multirow{2}{*}{ commentary } & \multicolumn{2}{|c|}{ criteria } \\
\hline & & Asset & turnover \\
\hline 1. & $\begin{array}{c}\text { Micro } \\
\text { businesses }\end{array}$ & Max. 50 million & Max. 300 million \\
\hline 2. & $\begin{array}{c}\text { Small } \\
\text { businesses }\end{array}$ & $\begin{array}{l}>50 \text { million - } 500 \\
\text { million }\end{array}$ & $\begin{array}{c}>300 \text { million - } 2.5 \\
\text { Billion }\end{array}$ \\
\hline 3. & $\begin{array}{c}\text { Medium } \\
\text { businesses }\end{array}$ & $\begin{array}{c}>500 \text { million }-1 \\
\text { billion }\end{array}$ & $\begin{array}{l}>2.5 \text { Billion - } 50 \\
\text { Billion }\end{array}$ \\
\hline
\end{tabular}

\section{3. (BMT) Baitul Maal wat tamwil}

Baitul Maal wat tamwil (BMT) is conceptually an economic institution which has a function of economic and social functions at the same time. Seen as a social function, role function can be determined from the Baitul Maal is a financial institution that serves as a fund manager who did not give priority to profit (nonprofit organization). These income sources derived from the presence charity, infaq, charity, endowments or other lawful sources to be distributed to the heirs according to the Islamic Shari'ah. The economy can be seen as a function of the role Baitut tamwil, is a financial institution whose activities raise funds and public funds to benefit motive (profit motive). Raising funds derived from the existence of third party deposits are distributed in the form of financing or investment on the basis of Shari'ah. (Aziz, 2004). BMT market segments in the study area consisted mostly of small micro entrepreneurs or MSMEs.

The second function of the BMT, BMT is more focused on how the function can actually run as expected, especially in helping to develop the business customer in this case lead to the MSMEs sector. One of them is the financing scheme. Financing can be done by BMT include:

1. Financing Mudharabah

2. Financing Musyarakah

3. Financing Murabahah

4. Financing Bai'Saman Ajil

5. Financing Qardhul Hasan

In addition to financing can be carried out by BMT to support the development of MSMEs in obtaining capital, BMT also focused on how to provide guidance to the financing provided to customers. With the aim to minimize default when the customer returns to the BMT financing, and so terpantaunya efforts being carried out by the customer. 
This was done by BMT with the account officer in charge to make the wisdom of the financing requirement at the direction of the manager, accept applications and conduct feasibility analysis of both administrative and business members, perform site surveys for the help and the customer service section of local leaders, the acceptance or rejection of the process financing request at the direction of the manager, finance redemptions after manager approval and coordination with the cashier, to provide guidance and assistance to the customer's business and perform necessary actions in response to financing problems, coordinating with all parts of the operational framework of BMT.

\section{Methodology}

This paper is a draft proposal for thesis research. It is based on literature review and descriptive approach. With the object of research is one of the BMT (Bandung, West Java) is BMT IT-QAN, where the author conducted field surveys looking for customer data using BMT financing services in IT-QAN.

\section{Finding}

BMT has a focal point in the community empowerment program for middle to lower a productive manner through the role and function of BMT scheme itself. Where BMT strategic role in reducing poverty can be seen from the economic activities that have social activities BMT (Baitul Mal) and business activities (at-Tamwil). Socio-economic activities carried out by the movement BMT zakat, sadaqah and waqf infaq. This is an advantage in reducing poverty BMT. By using this ZISWAF funds, BMT runs virtue loan products (qardhul hasan).

BMT social activities can be termed as a protection or social security to keep the community development process (customers) significantly, this case has reached many areas, especially in London. The instrument used is by highlighting two functions inherent in BMT, where:

1. Functions BMT as Baitul Maal is managing zakat, donation, and Sadaqah. In terms of utilization, a lot of programs that can be funded from these resources, such as human resource development (HRD), economic development, especially funding for small-micro businesses.

2. Functions BMT as Baitut tamwil in their work helping micro entrepreneurs, BMT not only funds but also able to assist clients attempt to reduce the amount of non -performing loans as a result of the failure of the customer's business.

Optimization of BMT role in the development of the real sector, in principle, is done by knowing the motivations and goals of the clients or potential clients when they apply for funding to BMT. There are several motivations and goals of clients or potential clients of the following types of appropriate financing can be identified as follows:

1. Customers or prospective customers who want capital goods or consumer goods with the intent to possess, then by looking at the characteristics mentioned above and after financing through feasibility studies and analysis, it can be given murabahah financing.

2. Customers or prospective customers who want additional working capital or working capital, financing it by looking at the characteristics mentioned above and after a feasibility study and analysis, it can be given of mudharabah financing or musyarakah financing.

3. Customers or prospective customers who want the benefits of an item, then by looking at the characteristics of the financing as described above, and after going through feasibility studies and analysis, it can be given ijarah financing.

4. Customers or prospective customers who need cash because of an immediate need (emergency), then by looking at the characteristics of the financing as described above, and after going through feasibility studies and analysis, it can be the product of the qardh al hasan.

Through increasing the capability and professionalism of managers BMT, and sensitivity analysis in order to provide financing appropriate for clients or potential clients then optimizing the role of BMT in the real economy can be implemented properly. In addition, indirectly when the manager performs analysis on current clients or potential clients do request financing then at that time also a process of education of the BMT to customers.

Education here is also needed by the client at all, because it is not denied by the empirical data that small community knowledge on the Islamic financing system is still very minimal. The small community just knowing the extent they could save and borrow capital to the banks, then they get their money and stay just to figure out how to recoup the loan. This makes the academics and practitioners in particular re-evaluate whether the bank socialization that they have done the maximum?

When the above optimization steps can already be implemented, still not guarantee that successful BMT function as a bridge in the development of MSME, but there are things that should be the center of attention is how BMT can perform more concrete actions related to the follow-up of the optimization steps that have been described previously. BMT is not impressed that the function can only be felt while when the initial customer request for capital, but can also be part of the process of development of MSME so that BMT actually took part in the success of MSME.

The expectation can be realized by optimizing the function of the second BMT as Baitut tamwil is to highlight business mentoring management instruments. So when customers have received venture capital, they have an obligation to be accountable for the capital that has been received. Is it the use of capital as well as possible to the needs of their 
business development or even used disproportionately? To be able to minimize it happens, it is necessary to moral responsibility which must be done by the financiers in this BMT.

In working out an ideal and effective assistance, there are two sectors that will be the goal of mentoring through:

\section{Supervision business or business carried on MSME}

The existence of a special officer who was given the responsibility to monitor the business and accompany clients to conduct business, which will be the special officer can serve also as a consultant (mentoring), help provide advice and solutions when the MSME complain of his business.

\section{Providing education about financial reporting}

According to empirical data, most of the MSME still find it difficult to manage funds. Between the use of funds for business and profit in it can sometimes still love mixed with personal funds, then it is necessary the existence of relevant financial reports and accurate. But to go in that direction needed media support such as mentoring by tutors who are experts in their field.

Over all, funding and mentoring program has become one of the solutions that are believed to help the client's business productivity. In addition, BMT has also successfully meet the challenges that fund raising is done by BMT is not only used for distribution or consumer financing, but also to finance productive. This condition can stimulate and create new entrepreneurial climate and help clients who have difficulty in running their business.

\section{Conclusion and Limitation}

BMT with financing and business assistance programs they have managed customer funds collected from multiple sources of funding in a way that is productive for customers. This will not only provide capital for the customers but also provide financing schemes and assistance in helping clients to improve their managerial skills in business. So the constraints on the ability to manage capital and effort can be completed. By doing mentoring programs such as training, BMT has been successful to optimize its role and function in empowering clients through mentoring schemes and financing productive. In a factual observation, by providing financing that is easily accessible to customers without any collateral and at the same complex requirements of business mentoring can create social entrepreneur spirit. Seem to provide a tool to improve the economic life of our customers and to improve their business performance.

This research is still preliminary research proposal that will be the thesis, so there is still a great challenge for further research. But in general the results can be seen when customers are eager to improve their living standards in meeting their basic needs.

\section{REFERENCES}

[1] Dariah, Atih Rohaeti (2012), Imporving Social Capital of Baitul Maal wat Tamwil (an Experience from BMT Lathifah, Sumedang, Indonesia), The International Journal of Social Sciences, Volume 4, Issue 1.

[2] Hamdan, Hamdino (2012), The Importance of Monitoring and Entreprenuership Concept as Future Direction of Microfinance in Malaysia: case study in the state of selangor, Journal of Global Entreprenuership, Volume 3, No. 1.

[3] Wahibur, Rokhman (2013), The Effect of Islamic Microfinance on Poverty Alleviation: Study in Indonesia, International Journal of Economics and Business, Volume 11, Issue 2.

[4] Hosen, Muhamad Nadratuzzaman (2012), Determinant Factors of the Successful of Baitul Maal wat Tamwil (BMT), International Journal of Academic Research in Economics and Management Sciences, Volume 1, No. 4.

[5] http://bmtitqan.org/content/view downloaded on February ${ }^{16 \text { th }}$ 2014

[6] http://www.tnp2k.go.id/id/kebijakan-percepatan/program-pe nanggulangan-kemiskinan-di-indonesia downloaded on March $^{30 \text { th }} 2014$

[7] http://www.saturnus-software.blogspot.com/Peranan-baitulmall-watt-tamwil-dalam-pemberdayaan-ukm.html downloaded on $\mathrm{March}^{30 \text { th }} 2014$

[8] http://www.academia.edu/melihat-usaha-mikro-kecil-dan-me nengah-(umkm)-sebagai-upaya-penanggulangan-kemiskinan .html downloaded on March ${ }^{30 t h} 2014$

[9] http://bps.go.id/publications/publikasi2013.php downloaded on March $^{\text {th }} 2014$ 